\title{
The Effectiveness of the Rule of Twenty Method in Reducing the Musculoskeletal Complaints among Educational Staffs
}

\author{
Ratih Andhika Akbar Rahma ${ }^{1 *}$, Dian Afif Arifah ${ }^{2}$, and Ario Ramadhan ${ }^{3}$ \\ ${ }^{1,2,3)}$ Occupational Safety and Health Study Program, Faculty of Health Science, \\ University of Darussalam Gontor \\ *) Correspondence e-mail: ratihandhika@ unida.gontor.ac.id \\ doi: https://doi.org/10.24843/JEI.2020.v06.i02.p01
}

Article Received: 12 April 2020; Accepted: 13 October 2020 Published: 31 December 2020

\begin{abstract}
Educational staff at the University of Darussalam Gontor sit in front of the computer screen for quite a long time, causing musculoskeletal complaints. Applying the Rule of Twenty (RoT) method is one way to minimize the risk of musculoskeletal disorders. This study aimed to measure the effectiveness of the Rule of Twenty methods in reducing the risk level of complaints of musculoskeletal disorders for the educational staff of the University of Darussalam Gontor. This study was a preexperimental research with one group pre-test - post-test design. The population in this study was the entire 68 educational staff of the University of Darussalam Gontor. Twenty-one (21) staff involved as a sample in this study and selected by purposive sampling method. The Nordic Body Map instrument was used to measure musculoskeletal complaint levels before and after the rule of twenty methods applied. Data were analyzed using the SPSS program version with autocorrelation test and paired t-test (CI: 95\%). The measurement results of musculoskeletal disorders among 21 respondents before and after the application of RoT were the level of action 1 (low-risk level). The result of the autocorrelation measurement showed that the value of Durbin Watson (DW) was 1.958 and DW (1.968) > DU (1.8116), indicates that there was no autocorrelation between variables. The paired t-test showed the value of $\mathrm{t}=5.760$ and $\mathrm{p}=0.0001$, indicates a significant difference between musculoskeletal disorders before and after the application of the Rule of Twenty Method $(p<0.05)$. Based on the result, this study found that the Rule of Twenty Method is effective in reducing the musculoskeletal disorders of the Educational Staffs, and potentially reduce $9.4 \%$ of musculoskeletal complaints among workers.
\end{abstract}

Keywords: educational staff, musculoskeletal disorders, the rule of twenty method

\section{Effektivitas Metode Rule of Twenty Menurunkan Keluhan Muskuloskeletal pada Staf Kependidikan}

\begin{abstract}
Abstrak
Staf kependidikan di Universitas Darussalam Gontor bekerja di depan layar monitor komputer dengan posisi kerja duduk dalam waktu yang lama sehingga dapat menyebabkan timbulnya keluhan muskuloskeletal. Metode Rule of Twenty (RoT) merupakan salah satu cara yang dapat diterapkan untuk mengurangi tingkat risiko keluhan muskuloskeletal. Penelitian ini bertujuan untuk menganalisis keefektivan metode Rule of Twenty dalam mengurangi tingkat risiko keluhan muskuloskeletal staf kependidikan Universitas Darussalam Gontor. Penelitian ini merupakan penelitian pra eksperimen dengan rancangan one group pretest posttest. Populasi dalam penelitian ini yaitu staf kependidikan Universitas Darussalam Gontor berjumlah 68 orang. Teknik pengambilan sampel dengan purposive sampling dengan jumlah sampel yaitu 21 orang. Pengambilan data menggunakan kuesioner Nordic Body Map. Analisis data dilakukan menggunakan program SPSS versi 20.0 dengan uji autokorelasi
\end{abstract}


dan uji t berpasangan. Hasil pengukuran keluhan muskuloskeletal pre dan post RoT yaitu tingkat aksi 1 (tingkat risiko rendah) sebanyak 21 orang. Hasil pengukuran uji autokorelasi diketahui bahwa nilai Durbin Watson $(D W)$ sebesar 1,958 maka DW $(1,968)>D U(1,8116)$ sehingga dinyatakan tidak ada autokorelasi antar variabel. Hasil uji beda yaitu nilai $t=5,760$ dan nilai $p=0,0001$ yang menunjukkan adanya perbedaan signifikan antara keluhan muskuloskeletal sebelum dan sesudah penerapan metode Rule of Twenty $(p<0,05)$. Metode Rule of Twenty efektif mengurangi keluhan muskuloskeletal Staf Kependidikan, karena terjadi penurunan keluhan sebesar 9,4\% antara sebelum dan sesudah penerapan RoT.

Kata kunci: metode rule of twenty, keluhan muskuloskeletal, staf kependidikan

\section{INTRODUCTION}

Occupational Health and Safety (OHS) is an important aspect of global development, especially in all industrial sectors. The implementation of OHS is one of the efforts to create occupational safety so it is good for health aspects and free from environmental pollution. The proper management of OHS will reduce occupational accidents, minimizing health disorders, and also increase work efficiency and productivity. One of the pillars of implementing OHS is to perform ergonomics in the workplace.

Ergonomics is the alignment of work with the workforce to provide efficiency and effectiveness in the workplace to increase the worker's comfort and productivity (Rahma, 2012). Poor application of ergonomics aspects in the workplace will potentially cause several health problems, especially Musculoskeletal Disorders (MSDs) that become the major effect of the ergonomics problem. Musculoskeletal Disorders (MSDs) are skeletal muscle disorders caused by a non-ergonomic work attitude that potentially accelerate the onset of fatigue and muscle pain among workers. The non-ergonomic activity which is done frequently for a long time (chronic) could impact permanent pain and becomes potential damage to the joints, muscles, tendons, ligaments, and other tissues. Working with such conditions continuously will result in disability and could causing job loss among workers (Aprico et al., 2019).

Adhyatma reported that the prevalence of Musculoskeletal Disorders (MSDs) based on symptomatic diagnosis reached $24.7 \%$ in Indonesia (Aprico et al., 2019. The results showed that the MSDs problem is one of the most occupational disease cases in various countries. In America, there are about 6 million cases per year or 300-400 of average cases per 1000 people in the workforce. Based on research on 9,482 workers in 12 districts or cities in Indonesia, the disorders experienced by most workers are MSDs (16\%), cardiovascular (8\%), nervous disorders (5\%), respiratory disorders (3\%), and ENT disorders (Prawira, et al., 2017).

One of the strategies to reduce musculoskeletal complaints initiated by Rosenfield and the American Optometric Association (AOA) is the Rule of Twenty methods (Aprico, et al., 2019). This method is one of the methods used to reduce the risk level of musculoskeletal complaints that are often experienced by workers. This method does not only focus on musculoskeletal complaints but also considers the disorders that effect eye health among workers (Rosenfield, 2013).

The visual symptoms experienced by computer users shows the most obvious expression of deficiencies in workplace ergonomics and the visual character of workers. Several studies show that visual symptoms occur in $75 \%$ to $90 \%$ of the people who work with computers. Research on the effectiveness of the Ergonomic Rule of Twenty methods in reducing the risk of MSDs among educational staff at the University of Darussalam Gontor can be a preliminary study to reduce the risk of MSDs in the workplace.

Based on research by Tofan, et al. (2016), there were musculoskeletal complaints among educational staff at the University of Darussalam Gontor. Most of the educational staff (12 
people) had low-grade of musculoskeletal complaints. The educational staff at the University of Darussalam Gontor work in front of a computer with a various sitting posture that leads to musculoskeletal complaints if it is done frequently for long periods. This study aimed to analyze musculoskeletal complaints before and after the application of the Rule of Twenty and analyze the effectiveness of implementing the Rule of Twenty methods to reduce musculoskeletal complaints among educational staff at the University of Darussalam Gontor (UNIDA Gontor).

\section{METHOD}

This research is a pre-experimental study with one group pre-test post-test design. The research was conducted at the University of Darussalam Gontor (UNIDA Gontor), Ponorogo. The population in this study was 68 educational staff at the UNIDA Gontor. The sampling technique used was purposive sampling and involved 21 respondents as a sample. Research variables, instruments, and data collection techniques are shown in Table 1.

Table 1

Research Instrument Variables and Data Collection Techniques

\begin{tabular}{lllll}
\hline \multicolumn{1}{c}{ Variable } & \multicolumn{1}{c}{ Operational Definition } & Instrument & Technique & Data Scale \\
\hline $\begin{array}{l}\text { Musculoskeletal } \\
\text { complaints }\end{array}$ & $\begin{array}{l}\text { Complaints in the skeletal } \\
\text { muscle ranged from mild to } \\
\text { very fatal complaints felt by } \\
\text { the patient }\end{array}$ & $\begin{array}{l}\text { NBM } \\
\text { Questionnaire }\end{array}$ & $\begin{array}{l}\text { Observation and } \\
\text { interview }\end{array}$ & Nominal \\
\hline $\begin{array}{l}\text { Rule of Twenty } \\
\text { (ROT) Method }\end{array}$ & $\begin{array}{l}\text { A method to reduce eye } \\
\text { health and musculoskeletal } \\
\text { complaints }\end{array}$ & $\begin{array}{l}\text { Android } \\
\text { application }\end{array}$ & $\begin{array}{l}\text { Instruction every 20 } \\
\text { minutes and 2 hours }\end{array}$ & Nominal \\
\hline Age & $\begin{array}{l}\text { The lifespan of the } \\
\text { educational staff in years } \\
\text { from birth to the present }\end{array}$ & Questionnaire & Interview & Ratio \\
\hline Years of service & $\begin{array}{l}\text { Years of service of the } \\
\text { educational staff from the } \\
\text { start of working at UNIDA } \\
\text { Gontor until the research } \\
\text { was carried out }\end{array}$ & Questionnaire & Interview & Ratio \\
\hline Sitting Duration & $\begin{array}{l}\text { Sitting duration of } \\
\text { educational staff when } \\
\text { working from the beginning } \\
\text { to the end of work per day }\end{array}$ & Questionnaire & Interview & Ratio \\
\hline $\begin{array}{l}\text { The duration of staring at } \\
\text { the computer screen from } \\
\text { the beginning to the end of } \\
\text { the work per day }\end{array}$ & Questionnaire & Interview & Ratio \\
\hline Screen time & & & & \\
\hline
\end{tabular}

Data were analyzed using SPSS program version 20.0 with autocorrelation test and paired t-test (dependent t-test). 


\section{RESULTS AND DISCUSSION}

The univariate analysis in this study described the characteristics of the respondents (educational staff) such as age, gender, years of service, sitting duration, and screen time. The results of the questionnaires from 21 educational staff at the University of Darussalam Gontor is shown in Table 2.

Table 2

Distribution of the Educational Staff Characteristics

\begin{tabular}{lcc}
\hline \multicolumn{1}{c}{ Variable } & Amount (n) & Percentage (\%) \\
\hline Age (year) & 17 & \\
$<30$ & 4 & 19 \\
$>30$ & 21 & 100 \\
Total & & \\
\hline Gender & 7 & 33.3 \\
Male & 14 & 66.7 \\
Female & 21 & 100 \\
Total & & \\
\hline Years of Service (year) & 16 & 76.2 \\
$1-3$ & 5 & 23.8 \\
$>3$ & 100 & 100 \\
Total & & \\
\hline Sitting duration (hour) & 5 & 23.8 \\
$<6$ & 16 & 76.2 \\
$>6$ & 21 & 100 \\
Total & & \\
\hline Screen time (hour) & 9 & 42.9 \\
$<6$ & 12 & 57.1 \\
$>6$ & 21 & 100 \\
Total & & \\
\hline
\end{tabular}

Based on Table 2 that described the distribution of educational staff characteristics, it is known that: the age of educational staff was mostly $<30$ years old $(81 \%)$ with the average age was 27 years old. The youngest staff was 24 years old and the oldest was 39 years old. People aged less than 30 years have a productive age where someone is still well-energized and able to do work optimally. Most of the educational staff were female (66.7\%). This is because the educational staff of the central campus of UNIDA Gontor was predominantly female. The most working period of educational staff was 1 to 3 years $(76.2 \%)$. The average years of service for educational staff were 2 years with the shortest work period was 6 months and the longest was 5 years. This is because UNIDA Gontor is a new university that requires a lot of educational staff to support the development process. The longest duration of sitting activity in the office in a day was $72.8 \%$. It is caused by many jobs that required them to sit for a long time in front of computer screens. The most screen time-frequency was $>6$ hours per day $(57.1 \%)$ because the main task of the staff is to work in front of a computer screen for 8 working hours in a day.

The measurement of pre-post of musculoskeletal complaints experienced and required action level 1 both before and after RoT intervention by educational staff at UNIDA Gontor is shown in Table 3. 
Table 3

Distribution of Musculoskeletal Complaints Measurement Results (Pre and Post RoT)

\begin{tabular}{ccccccc}
\hline \multicolumn{7}{c}{ Musculoskeletal Complaints } \\
\hline \multirow{2}{*}{$\begin{array}{c}\text { Action } \\
\text { Level }\end{array}$} & $\begin{array}{c}\text { Individual } \\
\text { Total Score }\end{array}$ & Risk level & \multicolumn{5}{c}{ Respondent amount } \\
\cline { 4 - 7 } & & & pre & $(\%)$ & post & $(\%)$ \\
\hline 1 & $28-49$ & Low & 21 & 100 & 21 & 100 \\
2 & $50-70$ & Moderate & 0 & 0 & 0 & 0 \\
3 & $71-91$ & High & 0 & 0 & 0 & 0 \\
4 & $92-112$ & Very high & 0 & 0 & 0 & 0 \\
\hline Total & & & 21 & 100 & 21 & 100
\end{tabular}

The measurement of musculoskeletal complaints based on the subjective body part complaint showed in Table 4.

Table 4

Results of Pre and Post RoT Musculoskeletal Complaints Measurement Percentage of the Educational Staff

\begin{tabular}{clccccc}
\hline \multirow{2}{*}{ No } & \multicolumn{1}{c}{ Complaints } & Respondent & \multicolumn{2}{c}{ Pre RoT } & \multicolumn{2}{c}{ Post RoT } \\
& & & \multicolumn{2}{c}{ Prevalence } & \multicolumn{2}{c}{ Prevalence } \\
& & & Pre & $(\%)$ & Post & $(\%)$ \\
\hline 1 & Upper neck & 21 & 10 & 47.6 & 6 & 28.6 \\
2 & Nape & 21 & 10 & 47.6 & 4 & 19 \\
3 & Left shoulder & 21 & 5 & 23.8 & 2 & 9.5 \\
4 & Right shoulder & 21 & 12 & 57.1 & 4 & 19 \\
5 & Left upper arm & 21 & 1 & 4.8 & 0 & 0 \\
6 & Back & 21 & 11 & 52.4 & 5 & 23.8 \\
7 & Right upper arm & 21 & 6 & 28.6 & 2 & 9.5 \\
8 & Waist & 21 & 14 & 66.7 & 12 & 57.1 \\
9 & Hip & 21 & 9 & 42.9 & 7 & 33.3 \\
10 & Buttocks & 21 & 4 & 19 & 0 & 0 \\
11 & Left elbow & 21 & 5 & 23.8 & 0 & 0 \\
12 & Right elbow & 21 & 6 & 28.6 & 1 & 4.8 \\
13 & Left forearm & 21 & 4 & 19 & 0 & 0 \\
14 & Right forearm & 21 & 8 & 38.1 & 3 & 14.3 \\
15 & Left wrist & 21 & 3 & 14.3 & 2 & 9.5 \\
16 & Right wrist & 21 & 9 & 42.9 & 5 & 23.8 \\
17 & Left hand & 21 & 2 & 9.5 & 2 & 9.5 \\
18 & Right hand & 21 & 5 & 23.8 & 2 & 9.5 \\
19 & Left thigh & 21 & 3 & 14.3 & 1 & 4.8 \\
20 & Right thigh & 21 & 3 & 14.3 & 0 & 0 \\
21 & Left knee & 21 & 6 & 28.6 & 1 & 4.8 \\
22 & Right knee & 21 & 5 & 23.8 & 3 & 14.3 \\
23 & Left calf & 21 & 6 & 28.6 & 4 & 19 \\
24 & Right calf & 21 & 7 & 33.3 & 6 & 28.6 \\
25 & Left ankle & 21 & 2 & 9.5 & 1 & 4.8 \\
26 & Right ankle & 21 & 4 & 19 & 0 & 0 \\
& & & & & &
\end{tabular}




\begin{tabular}{|c|c|c|c|c|c|c|}
\hline 27 & Left Foot & 21 & 2 & 9.5 & 1 & 4.8 \\
\hline 28 & Right foot & 21 & 2 & 9.5 & 1 & 4.8 \\
\hline \multicolumn{3}{|c|}{ Maximum value } & 14 & 66,7 & 12 & 57,1 \\
\hline \multicolumn{3}{|c|}{ Minimum value } & 1 & 4,8 & 0 & 0 \\
\hline \multicolumn{3}{|c|}{ Average } & 5,85 & 19 & 2,7 & 6,3 \\
\hline \multicolumn{3}{|c|}{ Modus } & 5 & 22,8 & 0 & 0 \\
\hline
\end{tabular}

Subjective body part complaints were measured before (pre) and after (post) RoT by NBM instrument. The respondents were asked to describe the musculoskeletal pain they felt in each 28 part of the body as shown in Table 4. It was a subjective measurement in NBM so the quality of assessment highly depends on the situation and conditions being experienced by the workforce as well as the expertise and experience of the observer (Tarwaka, 2010).

Based on Table 4, the average score of musculoskeletal complaints all over the body part before RoT is $5.85(19 \%)$ and decreased to $2.7(6,3)$ after RoT intervention. Besides the average, there was also a mode value indicates how often the score is appeared in the measurement (the value was 5). Next, the mode value in the post RoT assessment column was 0 . Based on Table 4 , there are 5 body parts that experience the highest complaints on the preRoT assessment: waist (14 people/66.7\%), right shoulder (12 people/57.1\%), back (11 people/52.4\%), upper neck (10 people/47.6\%), and nape (10 people/47.6\%).

To ensure the significant effect of RoT intervention in musculoskeletal complaints reduction, repeated measurement is required. In this section, respondents were asked to do RoT again and the musculoskeletal complaint was re-measured. The autocorrelation and paired ttests are required to find out other variables that potentially affect the musculoskeletal complaints among the educational staff. Furthermore, the comparison of musculoskeletal complaints between before and after RoT treatment is tested using paired t-test to find out if there's a significant difference.

The autocorrelation test is a statistical test to determine the correlation between confounding variables and dependent variables. Based on the results of the data analysis involving variables such as age, years of service, sitting duration, and screen time, there was no autocorrelation between these variables and the results of the SPSS test. The details can be seen in Table 5.

Table 5

Confounding Autocorrelation Test Results

\begin{tabular}{cccc}
\hline Model & R-value & $\mathrm{R}^{2}$ Value & Durbin Watson Value \\
\hline 1 & 0,886 & 0,785 & 1,958 \\
\hline
\end{tabular}

Based on Table 5, it is known that the Durbin Watson score (1.958) is higher compared to the Durbin Watson Table with $n=21$ and $k=4$ (DW=1.86), (DW $>D U)$. Based on this result, it can be concluded that there was no autocorrelation between variables. The results of data processing with SPSS version 20.0 using the paired t-test can be seen in Table 6 .

Based on Table 6, it can be seen that the value of $t=5.760$ and the value of $p=0.0001$. This showed a significant difference between musculoskeletal complaints before and after the application of the Rule of Twenty Method $(\mathrm{p}<0.05)$. 
The job demands of educational staff require them to sit in front of a computer screen for a long time every day. This condition potentially caused complaints at various parts of the body due to the static and monotone activity. Based on the result, there were 5 parts of the body experienced the highest musculoskeletal complaint and the felt by the most of respondents (educational staff): waist (15 people/66.7\%), right shoulder (12 people/57.1\%), back (11 people/52.4\%), and neck (10 people/47.6\%). Rahma (2012) stated that body parts or body segments measured in work posture (neck, body, arms, wrists, and feet) have a very high percentage of musculoskeletal complaints ( $\pm 99.43 \%$ ) compared to other body segments whose percentages are below $90 \%$.

Table 6

Difference Test Results between Musculoskeletal Complaints, Before and After Application of the Rule of Twenty Method

\begin{tabular}{cccc}
\hline & $\mathrm{n}$ & $\mathrm{t}$ Value & $\mathrm{p}$-Value \\
\hline $\begin{array}{c}\text { Musculoskeletal Complaints pre } \\
\text { and post RoT }\end{array}$ & 21 & 5,760 & 0,0001 \\
\hline
\end{tabular}

Many previous studies had examined the relationship between variables that can affect the level of musculoskeletal complaints. This study had conducted the same topic on the respondents (education staff). These results were used to decrease the risk level of musculoskeletal complaints among the respondents by applying RoT intervention.

The results of the initial measurement of the risk level of musculoskeletal complaints compared to the results of the final measurement (posttest) or after being given RoT treatment among educational staff showed that there was a significant decrease in musculoskeletal complaints by $9.4 \% \quad(\mathrm{p}<0.05)$. Based on the MSDs category, it is known that the musculoskeletal complaints among staffs were low. This result occurs because the work activity of the educational staff is static. The same thing was also reported by other researchers. Rahma (2012) in her research on the relationship between work posture of crane operators and complaints of musculoskeletal disorders at the Steel Slab Factory 1 Krakatau Steel Ltd. Cilegon, Banten found that musculoskeletal complaints among crane operator workers showed most equally score between low and moderate level complaints.

\section{CONCLUSION}

Based on the results and discussion, it can be concluded that there is no autocorrelation between the factors of age, years of service, sitting duration, and screen time. The Rule of Twenty methods is effectively reducing musculoskeletal complaints among educational staff. There was a decrease in musculoskeletal complaints by $9.4 \%$ after RoT implementation.

\section{REFERENCES}

Aprico, F., Arif, M.S., Muriyatmoko, D., Musthafa, A., Ramadhan, A., Phuspa, S.M. and Rahma, R.A.A. 2019. Kerja Sehat: Aplikasi Mobile Untuk Mengurangi Resiko Musculoskeletal Disorders (MSDs). Jurnal RESTI (Rekayasa Sistem dan Teknologi Informasi). Vol. 3(3):532-537.

Prawira, M.A., Yanti, N.P.N., Kurniawan, E., and Artha, L.P.W. 2017. Factors related to musculoskeletal disorders on students of Udayana University in 2016. Journal of Industrial Hygiene and Occupational Health. Vol 1(2):101-118. 
Rahma, R.A.A. 2012. "Hubungan Postur Kerja Operator Crane Dengan Keluhan Musculoskeletal Disorders Di Pabrik Slab Baja 1 PT. Krakatau Steel Cilegon Banten" (thesis). Surakarta: Sebelas Maret University.

Rosenfield, M. 2013. Visual Acuity: What is 20/20 Vision, Available at https://www.aoa.org/newsroom/five-tips-for-a-lifetime-of-healthy-vision (Accessed: 18 April 2019).

Tarwaka 2010. Ergonomi Industri. Second Edition First Printing. Surakarta: Harapan offset.

Tofan, A.P., Eka, R., and Rahma, R.A. 2017. Analysis of Factors Causing Musculoskeletal Disorders using RULA (Rapid Upper Limb Assessment) Method in Computer Operators. International Journal of Applied Environmental Sciences. Vol. 12(2):323340. 